\title{
Oceanography
}

CITATION

Durack, P.J. 2015. Ocean salinity and the global water cycle.

Oceanography 28(1):20-31, http://dx.doi.org/10.5670/oceanog.2015.03.

DOI

http://dx.doi.org/10.5670/oceanog.2015.03

COPYRIGHT

This article has been published in Oceanography, Volume 28, Number 1, a quarterly journal of The Oceanography Society. Copyright 2015 by The Oceanography Society. All rights reserved.

USAGE

Permission is granted to copy this article for use in teaching and research. Republication, systematic reproduction, or collective redistribution of any portion of this article by photocopy machine, reposting, or other means is permitted only with the approval of The Oceanography Society. Send all correspondence to: info@tos.org or The Oceanography Society, PO Box 1931, Rockville, MD 20849-1931, USA. 


\section{Ocean Salinity and the Global Water Cycle}

By Paul J. Durack

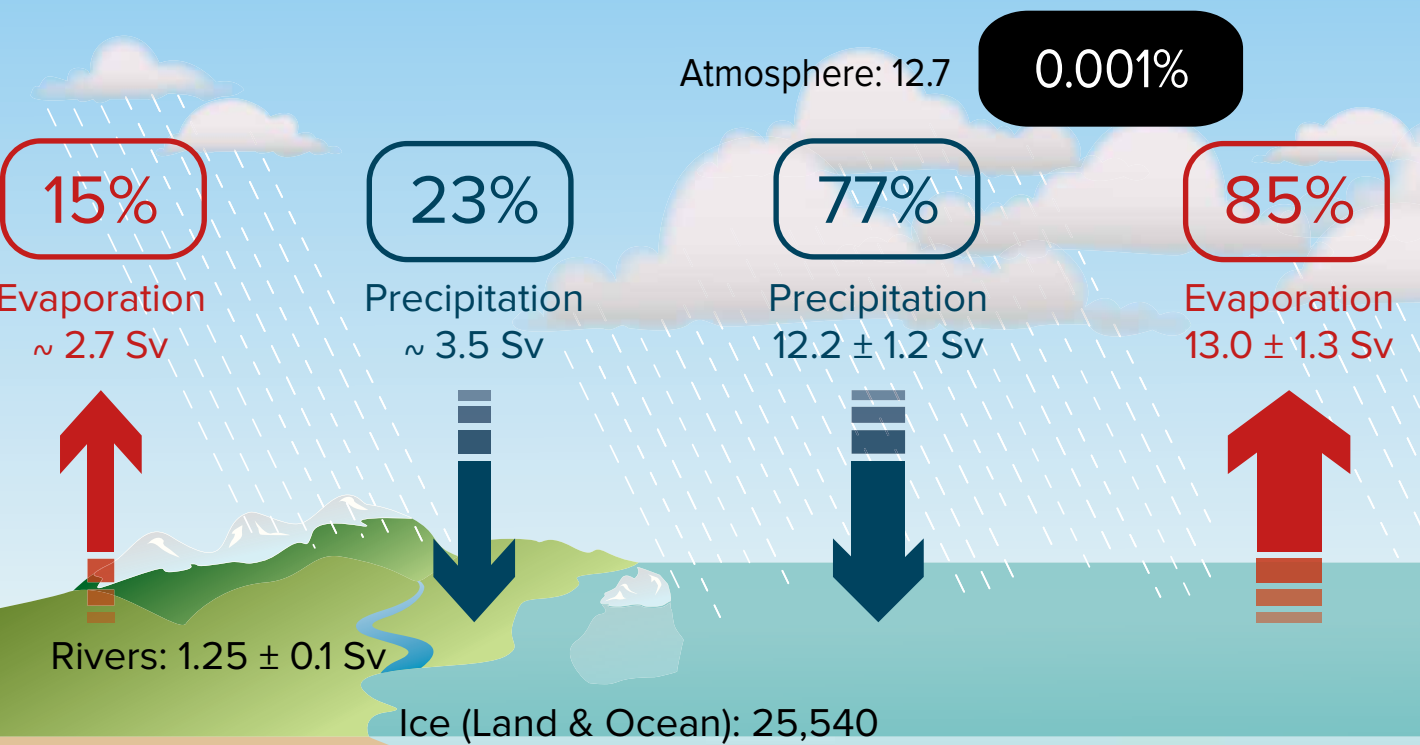

Land: 15,662

$2 \%$

Oceans: $1,335,040$

\section{$1 \%$}

\section{$97 \%$}

THE GLOBAL WATER CYCLE. The ocean contains the vast majority of Earth's water reservoirs, and $\sim 80 \%$ of surface water fluxes occur over the ocean. Reservoirs represented by solid boxes: $10^{3} \mathrm{~km}^{3}$, fluxes represented by arrows: Sverdrups $\left(10^{6} \mathrm{~m}^{3} \mathrm{~s}^{-1}\right)$. Sources: Baumgartner and Reichel (1975), Schmitt (1995), Trenberth et al. (2007), Schanze et al. (2010), Steffen et al. (2010) 
ABSTRACT. Alterations to the global water cycle are of concern as Earth's climate changes. Although policymakers are mainly interested in changes to terrestrial rainfall-where, when, and how much it's going to rain - the largest component of the global water cycle operates over the ocean where nearly all of Earth's free water resides. Approximately $80 \%$ of Earth's surface freshwater fluxes occur over the ocean; its surface salinity responds to changing evaporation and precipitation patterns by displaying salty or fresh anomalies. The salinity field integrates sporadic surface fluxes over time, and after accounting for ocean circulation and mixing, salinity changes resulting from long-term alterations to surface evaporation and precipitation are evident. Thus, ocean salinity measurements can provide insights into water-cycle operation and its longterm change. Although poor observational coverage and an incomplete view of the interaction of all water-cycle components limits our understanding, climate models are beginning to provide insights that are complementing observations. This new information suggests that the global water cycle is rapidly intensifying.

\section{INTRODUCTION}

When we talk about planet Earth, we are really referring to planet "Ocean." The global ocean covers $71 \%$ of Earth's surface and contains $97 \%$ of all free water stored. If we consider total fluxes of freshwater at Earth's surface, the global ocean dominates totals: $85 \%$ of evaporation and $77 \%$ of precipitation occurs at the ocean-atmosphere interface (Trenberth et al., 2007; Schmitt, 2008; Schanze et al., 2010; see global water cycle image on p. 20). Additionally, when talking about "global warming," we really mean "ocean warming." Due to its great heat capacity, the ocean has been taking up $93 \%$ of Earth's energy increase since 1971 (Rhein et al., 2013). With the ocean dominating global water cycle totals by every measure, and because it plays such a dominant role in changes to the planetary energy budget, it is clearly an important focus of climate research.

The importance of the ocean to climate cannot be overstated, and progress requires continuing to work toward better understanding of ongoing ocean variability and change. Although our understanding of global temperature changes is better quantified, the global water cycle is the climate system element most important to society. The ocean can provide unique insights into water-cycle operation, and by considering changes to ocean properties linked to the water cycle, insights to its long-term change. For this reason, accurate assessments of ocean salinity changes provide a novel method with which to investigate broadscale changes to Earth's water cycle in response to ongoing climate change.

\section{THE GLOBAL WATER CYCLE}

When referring to the global water cycle, regional precipitation $(\mathrm{P})$ is generally the key focus. The nature of $\mathrm{P}$, with its sporadic temporal and spatial patterns, along with the sparse terrestrial rain gauge observing network, makes it very difficult to accurately observe, let alone estimate, small changes over the observa-

Satellite-based sensors, in combination with in situ measurements, provide the only practical means of observing $\mathrm{P}$ over the ocean and land combined. Thermal infrared-based estimates are available from geostationary satellites at high frequency, but they have only modest skill at accurate instantaneous recording of rainfall intensity (Kidd and Huffman, 2011). Passive microwave data, available since 1987, have improved the reliability of $P$ retrievals and are particularly successful over the ocean, with landbased retrievals more approximate due tional record. to the effects of coastal and other complex terrain and the icy, high albedo polar regions $\left(>50^{\circ} \mathrm{S} / \mathrm{N}\right)$, which limit the accuracy of current algorithms. Computer algorithms have been available since 1979 to merge these independent data streams and produce coarse-resolution products (e.g., Global Precipitation Climatology Project [GPCP]; Huffman et al., 1997; Adler et al., 2003). Beginning in 1997, high-resolution products became available, coinciding with the launch of the Tropical Rainfall Measuring Mission (TRMM, extended by the Global Precipitation Measurement [GPM] mission, which launched in February 2014). In situ gauge data and satellite retrievals are often merged for climate studies (e.g., Huffman et al., 2007), keeping in mind that trends may be influenced by inhomogeneities in both the satellite and the sparse in situ data available (Hegerl et al., 2014; Maidment et al., 2014).

Regional evaporation (E) is more difficult to measure, as it depends on myriad localized conditions, from wind speed to the local vertical gradients of humidity and temperature. Consequently, $\mathrm{E}$ is normally estimated from measurements of meteorological variables using "bulk" formulas, or in a very few instances, from flux moorings that provide in situ measurements of all required meteorological conditions (see Josey et al., 2013, for a more complete description).

Evaporation minus precipitation (E-P) is a more accurate measure of the complete global water cycle than $\mathrm{P}$ or E alone, as both terms considered together (along with the smaller runoff term, R; Schanze et al., 2010) provide the water sources and sinks that comprise the global ocean's complete freshwater budget. Large global climatological mean discrepancies of order $25 \mathrm{~W} \mathrm{~m}^{-2}$ are apparent between independent current-generation surface heat flux (or, by definition, E) products, and suggest that similar issues exist with 
current climatological mean E-P estimates (Josey et al., 2013). Better quantification of the observed water cycle requires further work.

It has long been noted that the climatological mean sea surface salinity (SSS) and the surface E-P flux field are highly correlated (Wüst, 1936). This strong correlation reflects the long-term balance between ocean advection and mixing the ocean is the ultimate source of all terrestrial water (Gimeno et al., 2010; van der Ent and Savenije, 2013). The terrestrial component is further complicated as a result of human interference due to dams, diversions for irrigation, groundwater usage, and land-use changes. Additionally, water limitation (an issue not apparent with the ocean) and freshwater cycling and recycling (van der Ent

\section{The outlook is bright for a continuing improvement in our understanding of the oceanic water cycle due to the development of a series of new salinity observing technologies and platforms.}

processes and E-P fluxes at the ocean surface that maintain local salinity gradients. SSS provides an integrated and smoothed field from which the difficultto-measure and poorly constrained E-P fields-which set the spatial pattern of ocean SSS - can be inferred over the long term. The spatial structure of the global ocean surface and subsurface salinity field is maintained by ocean circulation and mixing, which are driven by ocean density gradients and surface winds that act at the ocean-atmosphere interface. This relationship between E-P and salinity motivates the "ocean rain gauge" concept (e.g., Schmitt, 2008). The hope is that improvements in salinity observations can lead to better estimates of the poorly observed E-P fluxes over the ocean and thus increase understanding of global water cycle operation, variability, and long-term change. Because oceanatmosphere freshwater fluxes comprise $\sim 80 \%$ of global surface totals, a better understanding of the oceanic water cycle should also aid our understanding of the smaller terrestrial component on which a large research focus is based-as et al., 2010) further obfuscate interpretation of long-term terrestrial changes (e.g., Greve et al., 2014). These issues are not relevant for the open ocean, and consequently do not affect assessments of salinity changes.

\section{OBSERVING OCEAN SALINITY}

A key advantage of using the ocean salinity field to study the global water cycle is that over the period of observational coverage, spatial patterns and climatological mean values are considered stable, with large deviations from present-day values having occurred during geologic $(\sim 100,000$-year) rather than climate ( 100-year) history (e.g., Rubey, 1951; Holland, 1972). This long-term salinity stability is useful for investigating small perturbations through time that result from forced changes driven by increasing anthropogenic $\mathrm{CO}_{2}$.

The earliest measurements of ocean salinity date back to 1772 , when Captain James Cook embarked on his second voyage to circumnavigate the globe. Since that time, ocean salinity has been measured using a number of different observing platforms, primarily on oceanographic research vessels, and more recently from automated profiling Argo floats (a more comprehensive history is detailed in Durack et al., 2013, and Gould et al., 2013). As described in more detail in articles in this special issue of Oceanography, more recently, surface salinity has also been measured using dedicated satellites. These data are providing exciting new insights into ocean processes.

Historical measurements of ocean salinity are very sparse in space and time due to the difficulty in accessing the large portion of the ocean that is far away from the nearest port. Hydrographic (salinity, temperature, and select chemical tracers) sampling first came to prominence in an early Atlantic Ocean survey undertaken from 1925-1927 on R/V Meteor. This expedition collected discrete (Nansen) bottle measurements obtained at ocean depths that were then analyzed for salinity and chemical properties, along with temperatures obtained using reversing thermometers. Since then, a number of coordinated expeditions have provided increasing global observational coverage. Some key expeditions include the International Geophysical Year (IGY, 1956-1960), the Geochemical Ocean Sections Study (GEOSECS, 1972-1978), and the Transient Tracers in the Ocean study (TTO, 1981-1983). By the 1970s, the significant variability associated with the ocean mesoscale had been recognized, and this led to the World Ocean Circulation Experiment (WOCE) Hydrographic Programme (WHP) that began in 1990 .

A new era of automated ocean observations began in 1999 with the development and implementation of the Argo float program (Gould et al., 2004). The goal of Argo is to continuously track the ocean's broad-scale structure, addressing limitations in our knowledge from discontinuous hydrographic observations and poor spatial and temporal observational coverage. In particular, Argo was implemented to improve ocean coverage in the poorly sampled Southern Hemisphere. Figure 1 
shows the time and latitudinally distributed historical evolution of salinity measurements. It is clear that while observations appear relatively continuous in time since $\sim 1950$, there is a strong bias toward Northern Hemisphere observations prior to Argo (CTD and bottle data).

\section{LONG-TERM CHANGES TO OCEAN SALINITY}

While limited historical observations hinder accurate assessments, long-term SSS changes have been estimated based on both trends fitted to ocean data (e.g., Freeland et al., 1997; Wong et al., 1999; Curry et al., 2003; Boyer et al., 2005; Delcroix et al., 2007; Gordon and Giulivi, 2008; Cravatte et al., 2009; Durack and Wijffels, 2010; Chen et al., 2012; Skliris et al., 2014) and comparisons of Argo-era (2003-present) data to historical ocean climatologies (e.g., Johnson and Lyman, 2007; Hosoda et al., 2009; Roemmich and Gilson, 2009; von Schuckmann et al., 2009; Helm et al., 2010). Although these studies suggest that long-term, broad-scale and coherent changes have occurred, it must be noted that because of the long time scales of ocean variability (e.g., Bullister et al., 2013; Durack et al., 2013; Kirtman et al., 2013; Latif, 2013), elucidating what is forced change (in response to increasing atmospheric $\mathrm{CO}_{2}$ ) and what is longer time scale natural variability remains the focus of ongoing research.

A number of studies have considered salinity changes on a global scale (Boyer et al., 2005; Hosoda et al., 2009; Roemmich and Gilson, 2009; Durack and Wijffels, 2010; Helm et al., 2010; Skliris et al., 2014). They show that surface patterns of multidecadal salinity change are remarkably similar to the mean salinity field (and also the mean E-P; see subsequent section). Rainfall (P) dominated regions such as the western Pacific warm (and fresh) pool, for example, have undergone a long-term freshening, and subtropical regions in the evaporation (E) dominated "desert latitudes" have generally increased in salinity in each basin. These observations have become clearer in recent assessments because of Argo data coverage (Figure 2A,B,D,E; blue denotes freshening regions and red denotes regions with enhanced salinities). In the broad scale, these changes suggest that the existing climatological mean gradients of SSS have intensified (Figure 2C and black contours in panels A, B, D, E), with increased values in the salinity maxima and decreased values in the salinity minima zones. Taking a step back and just considering the large basin-scale changes, there is a marked contrast between the freshening Pacific and the enhancing salinity in the Atlantic that is reinforcing the existing fresh (Pacific) versus salty (Atlantic) climatological mean contrast (Figure 2). These results are particularly prominent in the well-sampled Northern Hemisphere Pacific and Atlantic Oceans (Figures 1B and 2), and are in broadscale agreement with the regional studies of Curry et al. (2003) and Cravatte et al. (2009) for the Atlantic and Pacific, respectively. These SSS changes demonstrate that P-dominated wet regions get fresher and E-dominated dry regions saltier, following the expected response of an amplified water cycle (Allen and Ingram, 2002; Held and Soden, 2006).

These coherent changes to the global ocean salinity field are also apparent when considering subsurface waters, with salinity change patterns also largely enhancing the existing climatological mean (Figure 3). As noted for the surface salinity patterns, the interbasin contrast between the Atlantic (salty) and Pacific (fresh) also intensifies in the subsurface (e.g., Boyer et al., 2005; Roemmich and Gilson, 2009; von Schuckmann et al., 2009; Durack and Wijffels, 2010; Skliris et al., 2014). The penetration of salinity anomalies into the upper $1,000 \mathrm{~m}$ suggests that persistent surface changes from past decades have propagated into the ocean's interior, increasing salinity in the high-salinity subtropical waters and freshening those in the high latitudes. The salty subtropical gyre "bowls" in each basin, particularly those of the Southern Hemisphere Atlantic and Indian Oceans (not shown), show positive anomalies in the salinity maxima at depths shallower than $300 \mathrm{~m}$. The patterns found in the Northern Hemisphere
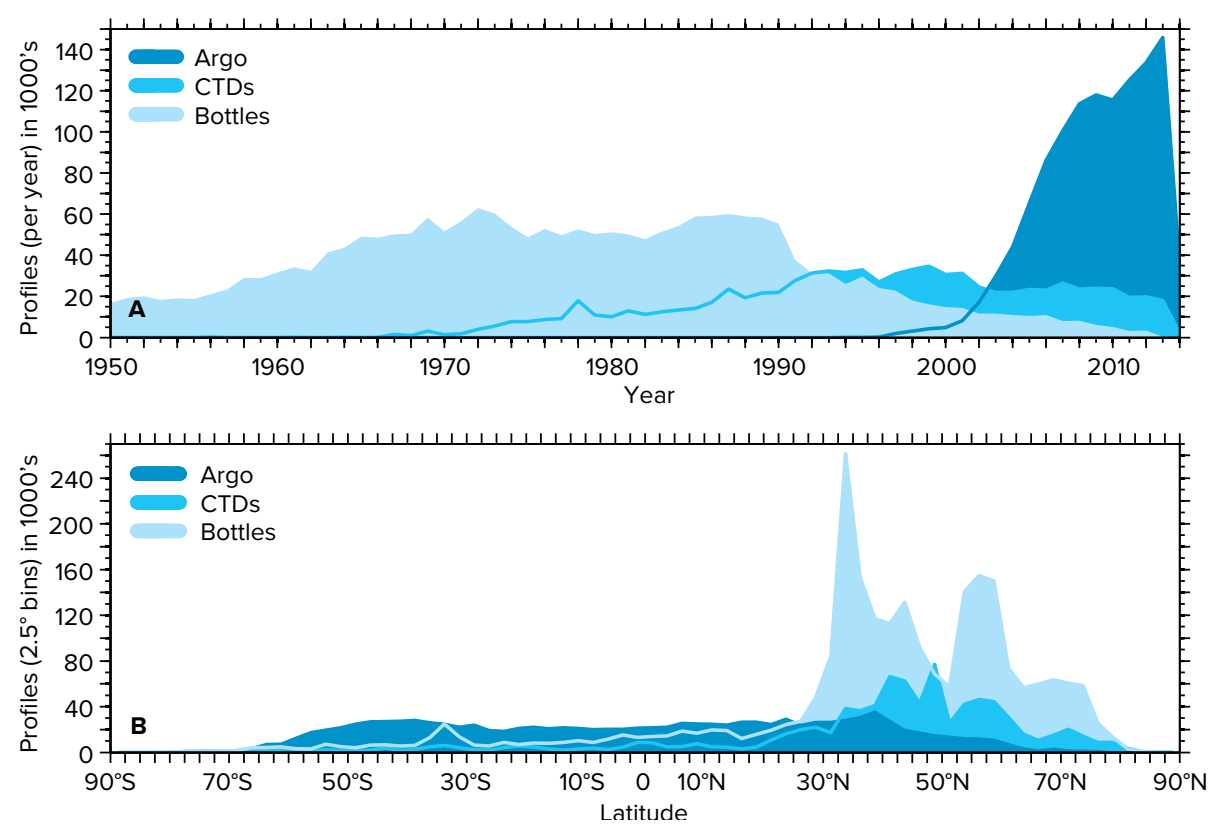

FIGURE 1. Ocean profile data from salinity observing platforms that comprise the World Ocean Database 2013, updated to 2014 (Boyer et al., 2013). Platform type for (A) per year (1950-2014) and (B) in $2.5^{\circ}$ zonal (latitude) bins for the period 1950-2014. The global nature of Argo program observations is evident in the even distribution of profiles across hemispheres. There is a clear Northern Hemisphere bias in the historical archive comprised of data derived from samples collected in Nansen bottles and by CTDs (instruments that measure conductivity, temperature, and depth). 
are less homogeneous across basins, which is not surprising considering the North Atlantic and North Pacific have very different water mass geographies (e.g., Talley, 2008).

Although these changes would appear consistent with theories of surface-forced salinity changes, coincident ocean warming must also be considered. Durack and Wijffels (2010) show that salinity changes expressed in an ocean density framework are driven by broad-scale surface warming. A temperature-driven lateral shift of an isopycnal (density) outcrop, which is generally poleward due to the broadscale warming, can lead to a migration through ocean surface climate zones (e.g., from a low salinity P-dominated region to a high salinity E-dominated region) and yield a subsurface salinity anomaly that is unrelated to surface E-P changes. Such changes are particularly relevant in regions of very strong meridional salinity gradients.

While these near-surface and subsurface changes appear to provide compelling evidence of long-term change to the ocean's salinity field and agree with theories of surface-forced ocean changes in response to ongoing climate change, the limited number of observations warrants continued consideration of coincident salinity variability (e.g., Dickson et al., 1988; Belkin et al., 1998; Delcroix et al., 2007; Reverdin, 2010; Durack et al., 2013) and its influence on long-term estimates of change. Such an assessment will be possible in the future as our observational understanding improves with the
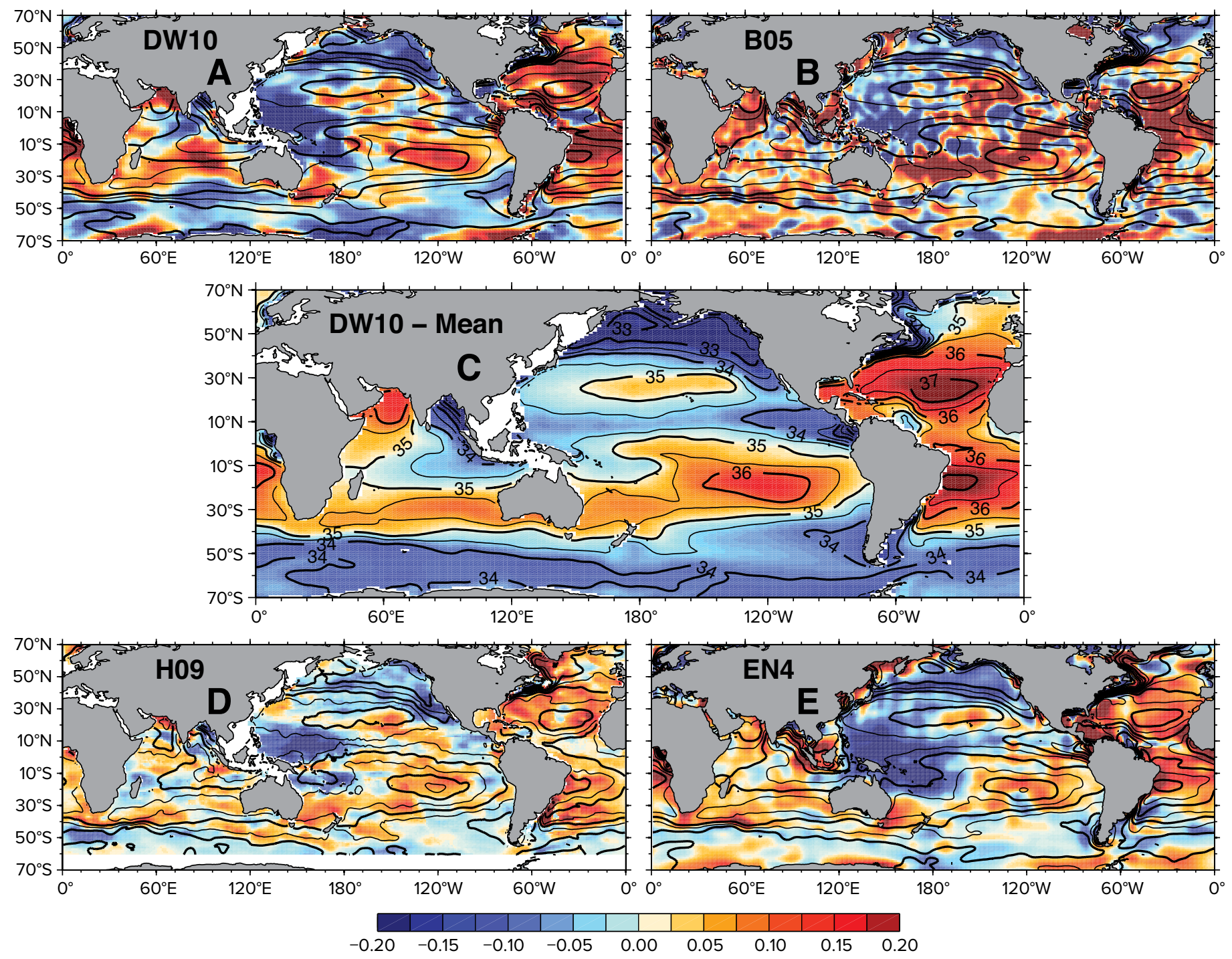

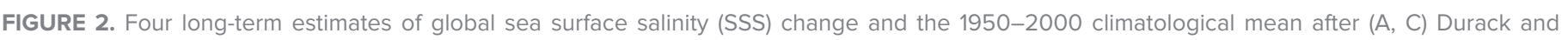

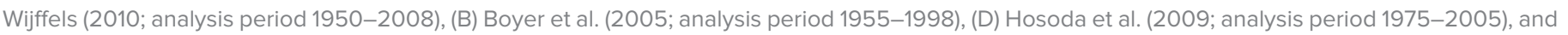

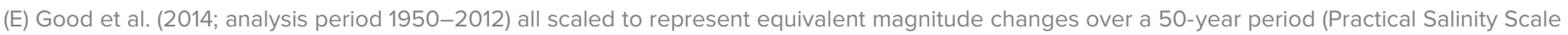

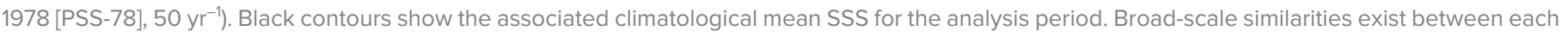

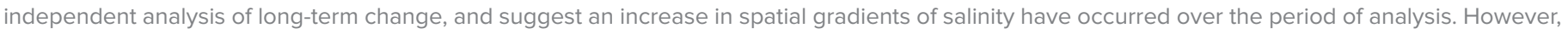

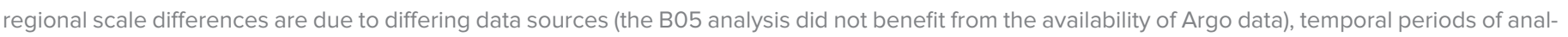
ysis, and analysis methodologies. Blue denotes freshening regions and red denotes regions with enhanced salinities. 
availability of new observing platforms that provide more comprehensive measurement coverage.

\section{LINKING OCEAN SALINITY CHANGES TO THE GLOBAL WATER CYCLE}

Measurable changes to the ocean's salinity field have been recorded over the period of observational coverage, but how do changing salinity patterns relate to longterm changes in the global water cycle? This question is difficult to answer considering the poor state of E-P observations, sparse salinity observations, and coincident ocean warming. What other tools can oceanographers use to investigate relationships between ocean salinity and water cycle (E-P) changes?

Since the late 1950s, numerical tools called General Circulation Models (GCMs) have been used in attempts to simulate the global climate system. Thanks to exponential growth in computing power, these models have become more complex over time and their realism (when compared to observed data) has consistently improved. The more modern model versions, known as AtmosphereOcean General Circulation Models (AOGCMs), include fully coupled atmosphere, ocean, and land-surface modules. Recent advances include Earth System Models (ESMs) that additionally incorporate modules for simulating interactions with biogeochemical climate components. As model complexity and horizontal resolution have increased, the fidelity of model simulations when compared to observation-based estimates has improved (e.g., Bellenger et al., 2013; Polade et al., 2013). However, it is worth noting that significant biases, such as the well-described Pacific Ocean "double ITCZ” (Intertropical Convergence Zone; e.g., Lin, 2007; Li and Xie, 2014) and Atlantic zonal sea surface temperature bias (e.g., Richter and Xie, 2008), along with others, still exist (e.g., Flato et al., 2013). Also, by necessity, models are simplified versions of reality and consequently do not include all the components that may strongly influence regional salinity features such as terrestrial ice sheets and glaciers. However, models have enabled new insights into the relationship between ocean salinity and the water cycle, which has strongly enhanced the understanding attainable from the limited observational data alone.

So, how do models compare with our observed view of Earth? Figure 4 compares observed climatological mean estimates of SSS (panel A) and E-P (panel C) to equivalent fields from a representative AOGCM from the Coupled Model Intercomparison Project Phase 5 (CMIP5; Taylor et al., 2012), ACCESS-1.0 (panels B and D). It is clear in Figure 4 that these fields are not identical; however, unforced climate variability can drive the marked regional changes that result in the largest discrepancies between these panels. When a more broad-scale view is considered, the realism of the model is impressive: for SSS, the model captures the broad-scale structure of the ocean's salinity field, with P-dominated fresh regions such as the western Pacific warm pool and the high-latitude North Pacific and Southern Oceans clearly evident. Similarly, the E-dominated subtropical gyres are well defined, and so too are their maxima at the approximate latitude for each basin independently. The salty Atlantic and fresh Pacific contrast is also evident. For the E-P field, the model captures regional features such as the P-dominated ITCZ, which is a principal driver of tropical atmospheric circulation. The model also captures the E-dominated subtropical cells and the regions of strong E-P gradients.
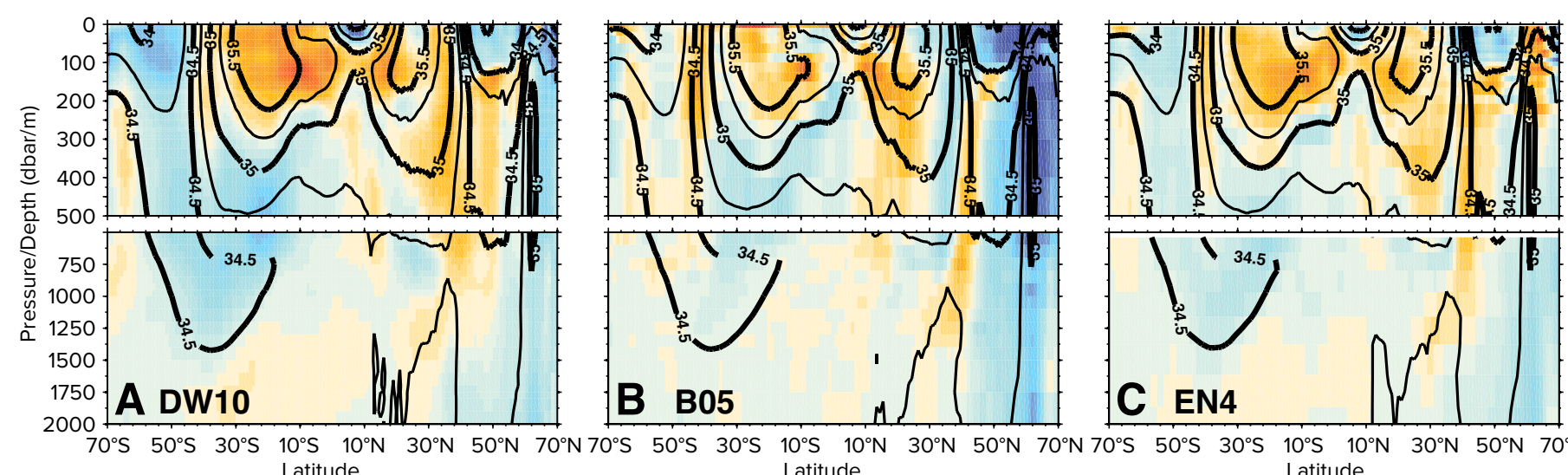

$70^{\circ} \mathrm{S} 50^{\circ} \mathrm{S} 30^{\circ} \mathrm{S} 10^{\circ} \mathrm{S} 10^{\circ} \mathrm{N} \quad 30^{\circ} \mathrm{N} 50^{\circ} \mathrm{N} 70^{\circ} \mathrm{N} 70^{\circ} \mathrm{S} 50^{\circ} \mathrm{S} 30^{\circ} \mathrm{S} 10^{\circ} \mathrm{S} 10^{\circ} \mathrm{N} 30^{\circ} \mathrm{N} 50^{\circ} \mathrm{N} 70^{\circ} \mathrm{N} 70^{\circ} \mathrm{S} 50^{\circ} \mathrm{S} 30^{\circ} \mathrm{S} 10^{\circ} \mathrm{S} \quad 10^{\circ} \mathrm{N} \quad 30^{\circ} \mathrm{N} 50^{\circ} \mathrm{N} 70^{\circ} \mathrm{N}$

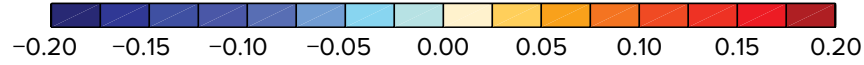

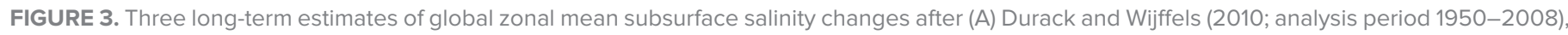

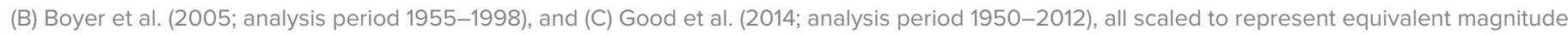

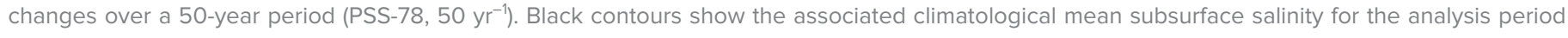

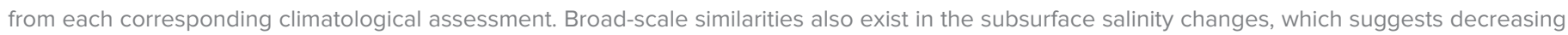

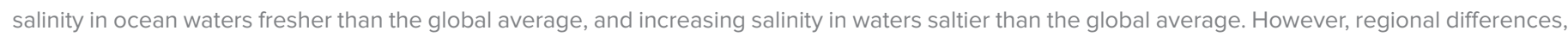
particularly in the high-latitude regions are apparent and are due to limited data sources, temporal periods of analysis, and analysis methodologies. 
Collectively, the model realism for the climatological mean at broad scales is impressive and warrants further consideration of simulated forced changes.

Using models and idealized experiments, how do the SSS and E-P fields interact and change? Williams et al. (2006) have shown the modeled dependence of the three-dimensional ocean salinity structure on E-P forcing, which decays (gradients dissipate) over a remarkably short time scale of 10-20 years if the E-P forcing is artificially removed. Further studies by Williams et al. (2007, 2010) show consistent amplification in surface and subsurface salinity gradients if the E-P field is doubled from present observed values. Using idealized oceanonly model simulations, Durack et al. $(2012,2013)$ also investigate the role of E-P changes as drivers of surface and subsurface salinity changes. They find that the three-dimensional salinity gradients are enhanced if $\mathrm{E}-\mathrm{P}$ surface fluxes are amplified at the surface, yielding comparable broad-scale simulated changes to the observed estimates discussed earlier. Collectively, these model studies support the E-P to SSS relationship, which underpins the "ocean rain gauge" concept and suggests that modeling studies may be useful proxies for providing insight into poorly observed longterm historical changes.

\section{CHANGES TO OCEAN SURFACE SALINITY-A MARKER OF THE}

\section{CHANGING GLOBAL WATER CYCLE}

To quantify salinity changes over the observed record, Durack et al. (2012) developed a technique to quantify and compare the strength of broad-scale salinity pattern amplification (PA) between observed estimates and models. They developed ocean basin (Atlantic, Pacific, and Indian) zonal averages for both the 50-year (nominally 1950-2000) climatological mean SSS and its corresponding change (see Figure 2, panels $\mathrm{C}$ and $\mathrm{A}$ ). The key advantage of this methodology is averaging across regional unforced climate variability, which is apparent in both models and observations, and also averaging across the patchy spatial patterns in observations that are a result of the sparse observational coverage through time. Additionally, the 50-year trends (the upper limit of observational coverage) provide change estimates that are believed to be mostly unaffected by unforced modes of decadal and multidecadal variability. To quantify SSS changes, a linear regression is undertaken on basin zonal mean quantities, which express the local anomaly from the global SSS mean salinity ( $\mathrm{x}$-axis; fresh regions are negative, salty positive) and the corresponding temporal trend (y-axis; freshening regions are negative, enhanced salinity positive). The resulting slope of this relationship was defined as the PA and the corresponding correlation coefficient (R) as the pattern correlation (PC). Using this technique, the salinity change results from both observations and models can be quantitatively compared to one another in a change per degree contextthe natural thermodynamic framework of water cycle amplification (Figure 5A). Using a per-degree framework allows a much larger suite of model simulations to be investigated, augmenting those from the CMIP5 "historical" experiment that correspond with the observed period, with projected simulations for the future. Figure 5 presents the results of this analysis, which show a strong linear dependence of salinity PA with temperature (Figure 5A). Symbol colors in the figure indicate the strength of the correlation (PC) between the climatological mean salinity and its change; red (a feature of the strongly forced future simulations

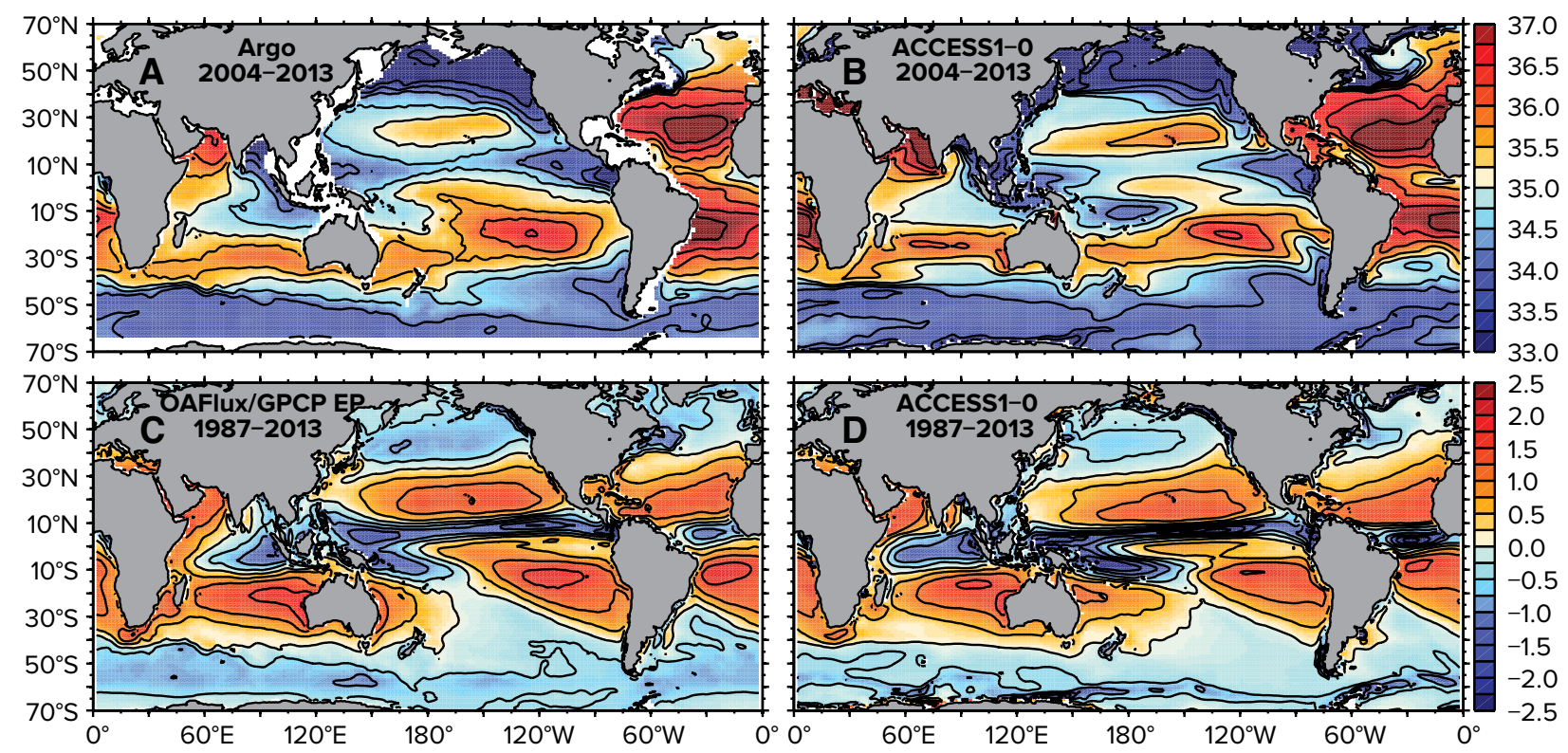

FIGURE 4. Climatological mean 2004-2013 near-surface salinity (SSS; PSS-78; A, B) and 1987-2013 evaporation minus precipitation (E-P; $\mathrm{m} \mathrm{yr}^{-1}$; C, D) in modern observations (A, C) and a representative model (ACCESS-1.0; B, D) from the CMIP5 suite. 
RCP85, RCP60, RCP45) is suggestive of a coherent PA, where the change field reports fresh getting fresher and salty getting saltier. The strongest results are found in the CMIP5 future simulations, with these relationships shown for the 20502100 period compared to 1950-2000 for observations and historical simulations, respectively. These model results suggest that an $8 \%$ PA for E-P change occurs per degree of global surface temperature change, a result that agrees with the simple thermodynamic relationship described by Clausius-Clapeyron (6-7\% increase in atmospheric water vapor per degree temperature change), and is consistent with results obtained from the previous CMIP3 model suite (Durack et al., 2012).

As coupled models simulate both ocean and atmospheric changes together, it is possible to investigate the coincident changes to E-P alongside the SSS changes that are strongly related to surface temperature change (Figure 5A). Figure 5B shows the relationship between the E-P PA and the SSS PA. Like the SSS-temperature relationship, there also appears to be a relationship between these variables, with increased SSS PA associated with increased E-P PA. However, unlike the strong linear relationship between SSS PA and temperature change, there is a larger spread, which suggests that variability and dynamics play a larger role in E-P changes. This is indicative of the enhanced unforced variability in E-P (of which $\mathrm{P}$ is the most variable) when compared to SSS change. As noted in the introduction, the SSS field acts to integrate the higher frequency and more sporadic E-P fluxes (in concert with ocean advection and mixing) and so provides an effective measure of persistent and ongoing forced change with a better signal-tonoise than E-P (Figure 5) or P changes alone (Durack et al., 2012, their Figure 2).

\section{DEPTH-INTEGRATED CHANGES TO} THE OCEAN'S SALINITY FIELD

Along with changes to near-surface salinity, the ocean's subsurface salinity field has been changing over the period of observational coverage (Figure 3). Are models also capturing these changes?

Data sparsity is an even larger issue in the deeper ocean $(>300 \mathrm{~m})$. Consequently, estimates of subsurface salinity changes are poorly constrained. Such observed changes to the depthintegrated ocean can provide a more rigorous test for models, as surface and mixed-layer variability is not apparent in the deeper ocean. As a result, deeper changes are likely more representative of persistent long-term changes, reflecting anomalies subducted into the ocean interior from their surface source regions on decadal times scales. If coherent and persistent subsurface salinity changes can be substantiated by additional salinity measurements, they will provide further evidence supporting the hypothesis of an enhanced water cycle.

Seawater density is a fundamental physical property that decreases (increases) when heat is added (removed). Similarly, salinity changes also drive density changes, with a density decrease (expansion) occurring in response to a decreasing salinity concentration, and a density increase (contraction) occurring in response to increasing
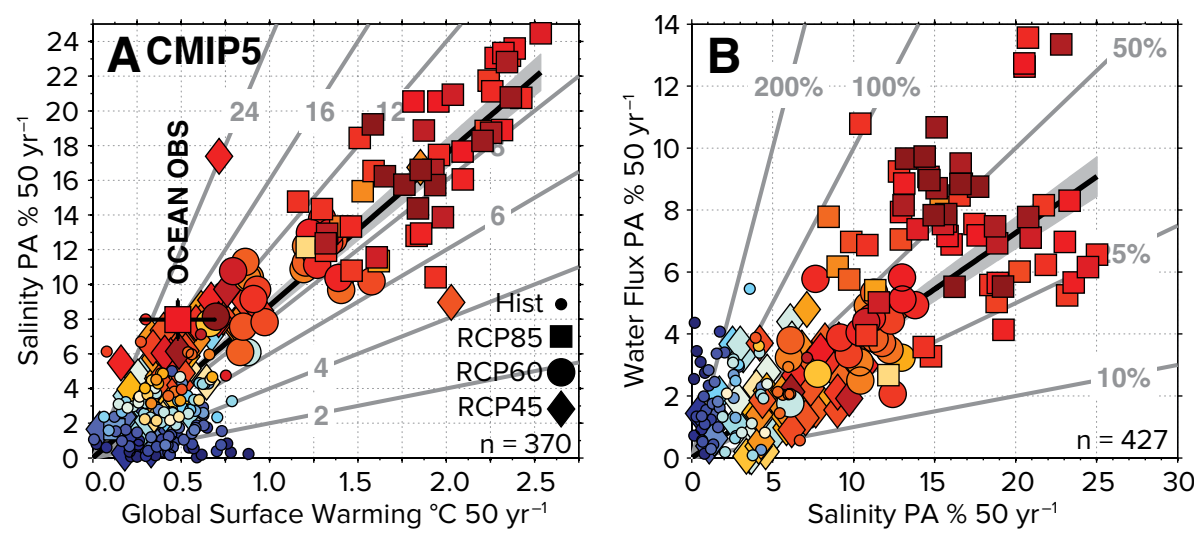

salinity concentrations. These steric (density) components are termed the thermosteric (heat) and halosteric (salt) properties of seawater. When integrated over the full ocean depth, steric changes impact local and global sea levels.

While there have been numerous investigations into observed changes to globally integrated thermosteric sea level (e.g., Church et al., 2013, and references therein), there have been relatively few that focused on halosteric changes (e.g., Antonov et al., 2002; Levitus et al., 2005; Ishii et al., 2006; Durack et al., 2014b), particularly at the larger basin scales. Comparing halosteric changes in both observed and simulated estimates is a more difficult challenge for climate models because the time scales for such anomalies to propagate into the deeper ocean are much longer than those of surface or mixed-layer changes. Additionally, the processes that drive modeled halosteric changes are less well understood than their thermosteric counterparts, and inherent variability in the model simulations leads to more divergent results and a corresponding lower signal-to-noise ratio.

The results presented in Figure 6

$$
\begin{array}{lllllllll}
0.0 & 0.1 & 0.2 & 0.3 & 0.4 & 0.5 & 0.6 & 0.7 & 0.8
\end{array}
$$

FIGURE 5. (A) 50-year near-surface salinity (SSS) pattern amplification (PA) plotted against coincident surface warming. (B) 50-year E-P PA plotted against coincident SSS. Small circles present results from the CMIP5 historical analysis experiment (for the period 1950-2000), and squares, large circles, and diamonds present results from the RCP85, RCP60, and RCP45 (analysis period 2050-2099) CMIP5 experiments, respectively. These simulations represent the most to least strongly forced future projections undertaken by the CMIP5 model suite. The gray shaded area bounds the pattern correlation (PC)-weighted linear best fit to the model ensemble for a line intersecting 0 in black. 
capture the depth-integrated halosteric anomaly from the surface to 2,000 dbar for a 50-year period, notionally 1950-2000. These results indicate regions where the depth-integrated water column has contracted (blue) because of a salinity increase, or expanded (orange) due to a freshening. Although there are some regional differences, on basin scales there is a strong correspondence between the observed and modeled results (Figure 6).

These results feature a coherent halosteric contraction in the Atlantic, with the largest magnitudes in the North Atlantic, and a tendency for halosteric expansion (depth-integrated freshening) in the Pacific. Focusing on observation in the Pacific (Figure 6A), models show the largest magnitudes of change around the Southern Hemisphere subtropics, regions that are ventilated in the high latitudes and show a near-surface freshening trend (Figure 2). The larger Southern Hemisphere halosteric magnitudes, compared to those in the Northern Hemisphere, are not a feature of other halosteric estimates of change (e.g., Ishii and Kimoto, 2009; Levitus et al., 2005) and may be symbolic of long-term change underestimates for the poorly sampled Southern Hemisphere (e.g., Gregory et al., 2004; Gouretski and Koltermann, 2007; Gille, 2008; Rhein et al., 2013; Durack et al., 2014a). It is worth noting that the basin-scale contrasts (Pacific halosteric expansion, Atlantic halosteric contraction) are only reproduced in models that include $\mathrm{CO}_{2}$ forcing (CMIP5
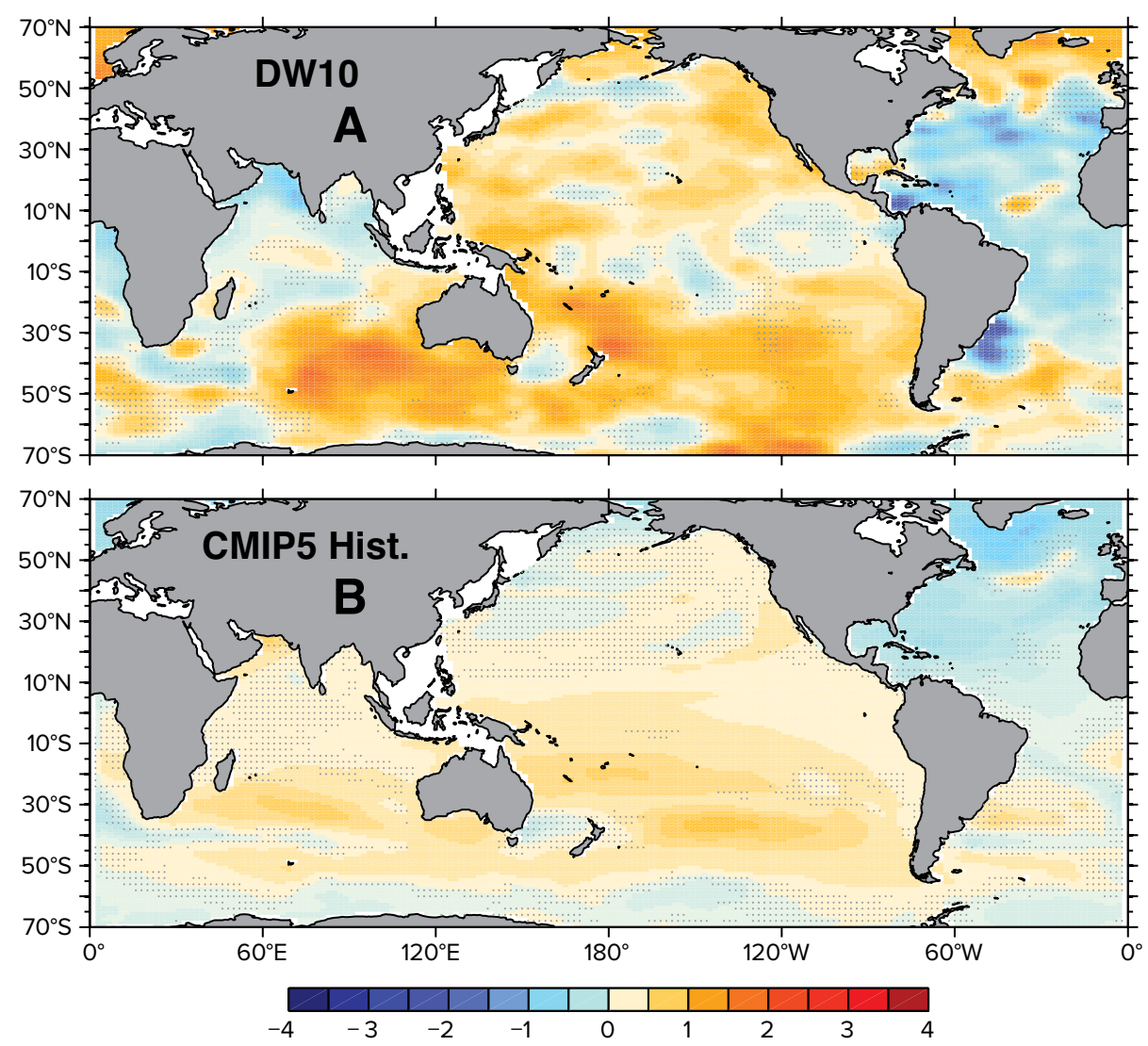

FIGURE 6. Long-term trends in the $0-2,000$ dbar halosteric anomaly presented as 50-year trends. Units are $\mathrm{mm} \mathrm{yr}^{-1}$. The observed trend (A) is from Durack and Wijffels (2010; analysis period 1950-2008), and the modeled trend (B) is from the CMIP5 historical simulations multimodel mean (MMM; analysis period 1950-2004). Stippling is used to mark regions where the observational result does not agree in sign with one other observed halosteric trend estimate (Ishii and Kimoto, 2009; analysis period 1950-2008) (A) and where less than 66\% of the contributing models do not agree in sign with the averaged (multimodel mean, or MMM) map obtained from the CMIP5 historical ensemble $(B)$.

historical simulations), whereas the corresponding halosteric (and thermosteric, not shown) basin-scale agreement with observed estimates is absent in simulations that exclude $\mathrm{CO}_{2}$ forcing (CMIP5 historical simulations with natural forcing only; Durack et al., 2014b).

Although there appears to be a compelling link between surface E-P forced salinity changes and subsurface salinity patterns in observations and in idealized model simulations (Durack et al., 2012), the effect of coincident warming (Durack and Wijffels, 2010) and the influence of ocean dynamical changes (Bouttes et al., 2012,2013 ) cannot yet be ruled out as the primary drivers of resolved changes.

\section{CONCLUSION}

The outlook is bright for a continuing improvement in our understanding of the oceanic water cycle due to the development of a series of new salinity observing technologies and platforms. Along with the existing Argo float array, two new satellite platforms have begun to provide near-global-ocean surface salinity observations. The Soil Moisture and Ocean Salinity (SMOS; Berger et al., 2002) platform was launched in November 2009 , and the dedicated surface salinity satellite Aquarius (Lagerloef et al., 2008) was launched in June 2011. Together, they are providing reprocessed data sets of threedaily to seasonal coverage and horizontal resolution of better than $150 \mathrm{~km}$ for the surface salinity field. Such new data are increasing our understanding of surface salinity variability and are resolving salinity at temporal and spatial resolutions never before seen. Preliminary studies are providing new insights into highfrequency variability in the tropical Pacific (Lee et al., 2012), salinity variability due to river outflows from the Amazon and Orinoco Rivers (Grodsky et al., 2012), and more refined and sharper seasonal gradients around the ITCZ in the Pacific and Atlantic ocean basins (Lagerloef et al., 2012). These satellites are measuring salinity responses and their variability in regions of currently ungauged 

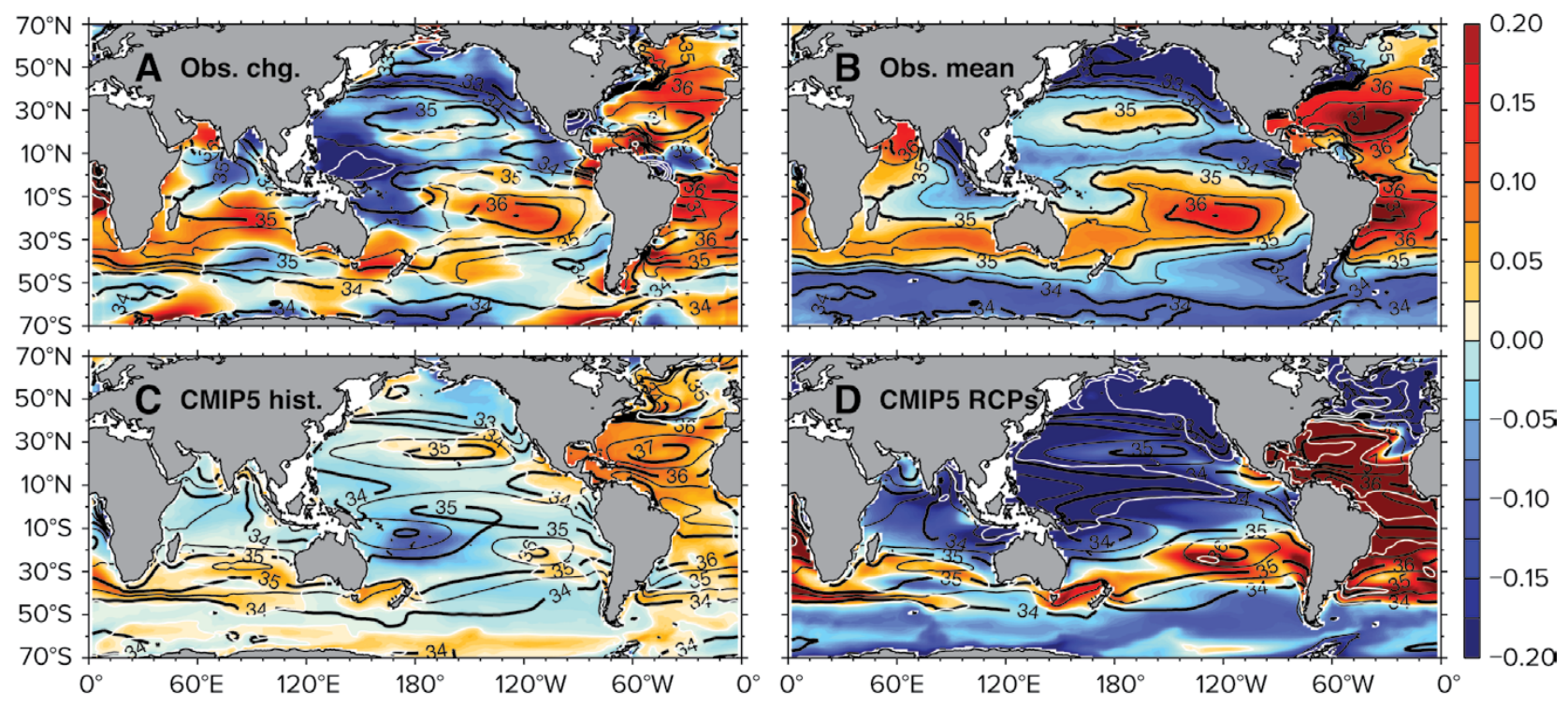

FIGURE 7. Maps of 50-year salinity trends for the near-surface ocean. (A) The 1950-2000 observational change and (B) the corresponding 1950-2000 climatological mean of Durack and Wijfels (2010; analysis period 1950-2008). (C) Modeled changes for the 1950-2000 period from the CMIP5 historical experiment MMM (analysis period 1950-1999) and (D) 2050-2099 future projected changes for the most strongly forced RCP85 experiment MMM (analysis period 2050-2099). Black contours bound the climatological mean salinity associated with each map, and white contours bound the salinity trend in increments of 0.25 PSS-78.

river and groundwater outflows and in areas of high seasonal precipitation. They are also providing observational coverage in ocean regions that the Argo program has been unable to access, such as the Indonesian seas and heavily pirated regions such as the tropical Indian Ocean. Though an unintended capability of Aquarius but the primary mission objective of SMOS, both satellites are also providing new insights into soil moisture for the top $5 \mathrm{~cm}$ of the global land surface-a bonus that further improves our global water cycle understanding.

These new satellite data are complemented by the Salinity Processes in the Upper-ocean Regional Study (SPURS) field experiment in the North Atlantic (SPURS-1), which set out to assess the salinity budget of this ocean region's salinity maximum. This special issue of Oceanography highlights many new and exciting results from the SPURS-1 experiment, and further insights are expected from SPURS-2 (Farrar et al., 2014), which will focus on a high rainfall and salinity minima region in the tropical Pacific. By examining both the Atlantic and Pacific, the two SPURS experiments promise to greatly illuminate the oceanic processes that govern regions of high and low surface salinity.

What's in store for future research into the oceanic water cycle and ongoing changes to ocean salinity? Considering that models appear to capture most of the broad-scale features of both climatological mean E-P and SSS (Figure 4), further work is needed to quantitatively examine modeled variability estimates and compare the results to the new observations available from Argo floats, the SMOS and Aquarius satellite missions, and process-based studies such as SPURS. If modeled variability estimates stand up well against these new observational insights, then more confidence can be placed in the changes models suggest will occur to the global water cycle as a result of ongoing $\mathrm{CO}_{2}$ forcing.

CMIP5 models project significant changes will continue to occur to the ocean's salinity field in response to climate change, with future changes in broad agreement with resolved observed changes (Figure 7). As the ocean constitutes Earth's largest possible rain gauge, it is time that we paid more attention to what it is trying to tell us. @
ACKNOWLEDGEMENTS. This paper is a contribution to the US Department of Energy, Office of Science, Climate and Environmental Sciences Division, Regional and Global Climate Modeling Program under contract DE-AC52-07NA27344. The author thanks J. Durack of the University of California, San Francisco, and the three guest editors (R. Schmitt, F. Bryan, and E. Lindstrom) for helpful comments with early drafts of this manuscript. The sources of observed data used in this study are acknowledged: T. Boyer (B05), S. Hosoda (H09), S. Good (EN4), and the International Argo Program and the national programs that contribute to it. The efforts of the World Climate Research Programme's Working Group on Coupled Modelling, which is responsible for CMIP, is acknowledged, and considerable thanks goes to the climate modeling groups for producing and making available their model output. For CMIP, the US Department of Energy's Program for Climate Model Diagnosis and Intercomparison provides coordinating support and led development of software infrastructure in partnership with the Global Organization for Earth System Science Portals. The DW10 data presented in this study can be downloaded from the CSIRO Ocean Change website at www.cmar.csiro.au/oceanchange. LLNL Release \# LLNL-JRNL-665262.

\section{REFERENCES}

Adler, R.F., G.J. Huffman, A. Chang, R. Ferraro, P. Xie, J. Janowiak, B. Rudolf, U. Schneider, S. Curtis, D. Bolvin, and others. 2003. The Version-2 Global Precipitation Climatology Project (GPCP) monthly precipitation analysis (1979-present). Journal of Hydrometeorology 4:1,147-1,167, http://dx.doi.org/10.1175/1525-7541(2003)004 $<1147$ :TVGPCP>2.0.CO;2.

Allen, M.R., and W.J. Ingram. 2002. Constraints on future changes in climate and the hydrologic cycle. Nature 419:224-232, http://dx.doi.org/10.1038/ nature01092. 
Antonov, J.I., S. Levitus, and T.P. Boyer. 2002. Steric sea level variations during 1957-1994: Importance of salinity. Journal of Geophysical Research 107(C12), 8013, http://dx.doi.org/ 10.1029/2001JC000964.

Baumgartner, A., and E. Reichel. 1975. The World Water Balance: Mean Annual Global, Continental and Maritime Precipitation, Evaporation and Runoff. Elsevier Science Ltd. Amsterdam, 179 pp.

Belkin, I.M., S. Levitus, J. Antonov, and

S.-A. Malmberg. 1998. "Great Salinity

Anomalies" in the North Atlantic. Progress in Oceanography 41:1-68, http://dx.doi.org/10.1016/ S0079-6611(98)00015-9.

Bellenger, H., E. Guilyardi, J. Leloup, M. Lengaigne, and J. Vialard. 2013. ENSO representation in climate models: From CMIP3 to CMIP5. Climate Dynamics 42:1,999-2,018, http://dx.doi.org/10.1007/ s00382-013-1783-z.

Berger, M., A. Camps, J. Font, Y. Berr, J. Miller, J. Johannessen, J. Boutin, M.R. Drinkwater, N. Skou, N. Floury, and others. 2002. Measuring ocean salinity with ESA's SMOS Mission. ESA Bulletin 111:113-121, http://esamultimedia.esa.int/ docs/Cryosat/ESABulletin111-SMOSOSactivities.pdf.

Bouttes, N., J.M. Gregory, T. Kuhlbrodt, and R.S. Smith 2013. The drivers of projected North Atlantic sea level change. Climate Dynamics 43:1,531-1,544, http://dx.doi.org/10.1007/s00382-013-1973-8.

Bouttes, N., J.M. Gregory, T. Kuhlbrodt, and T. Suzuki. 2012. The effect of windstress change on future sea level change in the Southern Ocean. Geophysical Research Letters 39, L23602, http://dx.doi.org/10.1029/2012GL054207.

Boyer, T.P., J.I. Antonov, O.K. Baranova, C. Coleman, H.E. Garcia, A. Grodsky, D.R. Johnson, R.A. Locarnini, A.V. Mishonov, T.D. O'Brien, and others. 2013. World Ocean Database 2013. S. Levitus, ed., A. Mishonov, technical ed., NOAA Atlas NESDIS 72, 209 pp., http://data.nodc.noaa.gov/ woa/WOD13/DOC/wod13_intro.pdf.

Boyer, T.P., S. Levitus, J.I. Antonov, R.A. Locarnini, and H.E. Garcia. 2005. Linear trends in salinity for the world ocean, 1955-1998. Geophysical Research Letters 32, L01604, http://dx.doi.org/ 10.1029/2004GL021791.

Bullister, J.L., M. Rhein, and C. Mauritzen. 2013. Deepwater formation. Pp. 227-253 in Ocean Circulation and Climate: A 21st Century Perspective. G. Siedler, S.M. Griffies, J. Gould, and J.A. Church, eds, International Geophysics, vol. 103, Academic Press, Elsevier, Oxford, UK, http://dx.doi.org/10.1016/ B978-0-12-391851-2.00010-6.

Chen, J., R. Zhang, H. Wang, Y. An, P. Peng, and W. Zhang. 2012. Isolation of sea surface salinity maps on various timescales in the tropical Pacific Ocean. Journal of Oceanography 68(5):687-701, http://dx.doi.org/10.1007/s10872-012-0126-8.

Church, J.A., P.U. Clark, A. Cazenave, J.M. Gregory, S. Jevrejeva, A. Levermann, M.A. Merrifield, G.A. Milne, R.S. Nerem, P.D. Nunn, and others. 2013. Sea level change. Pp. 1,137-1,216 in Climate Change 2013: The Physical Science Basis. Contribution of Working Group I to the Fifth Assessment Report of the Intergovernmental Panel on Climate Change. T.F. Stocker, D. Qin, G.-K. Plattner, M. Tignor, S.K. Allen, J. Boschung, A. Nauels, Y. Xia, V. Bex, and P.M. Midgley, eds, Cambridge University Press, Cambridge, UK, and New York, NY, http://dx.doi.org/10.1017/ CBO9781107415324.026.

Cravatte, S., T. Delcroix, D. Zhang, M. McPhaden, and J. LeLoup. 2009. Observed freshening and warming of the western Pacific Warm Pool. Climate Dynamics 33:565-589, http://dx.doi.org/10.1007/ s00382-009-0526-7.
Curry, R., B. Dickson, and I. Yashayaev. 2003. A change in the freshwater balance of the Atlantic Ocean over the past four decades. Nature 426:826-829, http://dx.doi.org/10.1038/ nature02206

Delcroix, T., S. Cravatte, and M.J. McPhaden. 2007. Decadal variations and trends in tropical Pacific sea surface salinity since 1970. Journal of Geophysical Research 112, C03012, http://dx.doi.org/10.1029/ 2006JC003801.

Dickson, R.R., J. Meincke, S.-A. Malmberg, and A.J. Lee. 1988. The "great salinity anomaly" in the Northern North Atlantic 1968-1982. Progress in Oceanography 20:103-151, http://dx.doi.org/ 10.1016/0079-6611(88)90049-3.

Durack, P.J., P.J. Gleckler, F.W. Landerer, and K.E. Taylor. 2014a. Quantifying underestimates of long-term upper-ocean warming. Nature Climate Change 4:999-1,005, http://dx.doi.org/10.1038/ nclimate2389.

Durack, P.J., and S.E. Wijffels. 2010. Fifty-year trends in global ocean salinities and their relationship to broad-scale warming. Journal of Climate 23:4,342-4,362, http://dx.doi.org/ 10.1175/2010JCLI3377.1.

Durack, P.J., S.E. Wijffels, and T.P. Boyer. 2013. Long-term salinity changes and implications for the global water cycle. Pp. 727-757 in Ocean Circulation and Climate: $A$ 21st Century Perspective. G. Siedler, S.M. Griffies, J. Gould, and J.A. Church, eds, International Geophysics, vol. 103, Academic Press, Elsevier, Oxford, UK, http://dx.doi.org/10.1016/ B978-0-12-391851-2.00028-3.

Durack, P.J., S.E. Wijffels, and P.J. Gleckler. 2014b. Long-term sea-level change revisited: The role of salinity. Environmental Research Letters 9, 114017, http://dx.doi.org/10.1088/1748-9326/9/11/114017.

Durack, P.J., S.E. Wijffels, and R.J. Matear. 2012. Ocean salinities reveal strong global water cycle intensification during 1950 to 2000 . Science 336:455-458, http://dx.doi.org/10.1126/ science.1212222.

Farrar, J.T., R. Schmitt, L. Rainville, W. Asher, B. Hodges, A. Jessup, F. Bingham, A. Shcherbina, W.S. Kessler, L. Centurioni, and others. 2014. SPURS-2: Diagnosing the Physics of a RainfallDominated Salinity Minimum. Report of a Workshop in Pasadena, April 16-18 2014. 17 pp., http://spurs.jpl.nasa.gov/pdf/SPURS-2_ WhitePaper_v12rev.pdf.

Flato, G., J. Marotzke, B. Abiodun, P. Braconnot, S.C. Chou, W. Collins, P. Cox, F. Driouech, S. Emori, V. Eyring, and others. 2013. Evaluation of climate models. Pp. 741-866 in Climate Change 2013: The Physical Science Basis. Contribution of Working Group I to the Fifth Assessment Report of the Intergovernmental Panel on Climate Change. T.F. Stocker, D. Qin, G.-K. Plattner, M. Tignor, S.K. Allen, J. Boschung, A. Nauels, Y. Xia, V. Bex, and P.M. Midgley, eds, Cambridge University Press, Cambridge, UK, and New York, NY, http://dx.doi.org/10.1017/CBO9781107415324.020.

Freeland, H., K. Denman, C.S. Wong, F. Whitney, and R. Jacques. 1997. Evidence of change in the winter mixed layer in the Northeast Pacific Ocean Deep-Sea Research Part I 44(12):2,117-2,129, http://dx.doi.org/10.1016/S0967-0637(97)00083-6.

Gille, S.T. 2008. Decadal-scale temperature trends in the Southern Hemisphere ocean. Journal of Climate 21:4,749-4,765, http://dx.doi.org/ 10.1175/2008JCLI2131.1.

Gimeno, L., A. Drumon, R. Nieto, R.M. Trigo, and A. Stohl. 2010. On the origin of continental precipitation. Geophysical Research Letters 37, L13804, http://dx.doi.org/10.1029/2010GL043712.

Good, S.A., M.J. Martin, and N.A. Rayner. 2014. EN4: Quality controlled ocean temperature and salinity profiles and monthly objective analyses with uncertainty estimates. Journal of Geophysical Research 118:6,704-6,716, http://dx.doi.org/ 10.1002/2013JC009067.

Gordon, A.L., and C.F. Giulivi. 2008. Sea surface salinity trends over fifty years within the subtropical North Atlantic. Oceanography 21(1):20-29, http://dx.doi.org/10.5670/oceanog.2008.64.

Gould, J., D. Roemmich, S. Wijffels, H. Freeland, N. Ignaszewsky, X. Jianping, S. Pouliquen, Y. Desaubies, U. Send, K. Radhakrishnan, and others. 2004. Argo profiling floats bring new era of in situ ocean observations. Eos, Transactions American Geophysical Union 85(19):185, http://dx.doi.org/10.1029/2004EO190002.

Gould, J., B. Sloyan, and M. Visbeck. 2013. In situ ocean observations: A brief history, present status, and future directions. Pp. 59-81 in Ocean Circulation and Climate: $A$ 21st Century Perspective. G. Siedler, S.M. Griffies, J. Gould, and J.A. Church, eds, International Geophysics, vol. 103, Academic Press, Elsevier, Oxford, UK, http://dx.doi.org/10.1016/ B978-0-12-391851-2.00003-9.

Gouretski, V., and K.P. Koltermann. 2007. How much is the ocean really warming? Geophysical Research Letters 34, L01610, http://dx.doi.org/ 10.1029/2006GL027834

Gregory, J.M., H.T. Banks, P.A. Stott, J.A. Lowe, and M.D. Palmer. 2004. Simulated and observed decadal variability in ocean heat content. Geophysical Research Letters 31, L15312, http://dx.doi.org/10.1029/2004GL020258.

Greve, P., B. Orlowsky, B. Mueller, J. Sheffield, M. Recihstein, and S.I. Seneviratne. 2014. Global assessment of trends in wetting and drying over land. Nature Geoscience 7:716-721, http://dx.doi.org/10.1038/ngeo2247.

Grodsky, S.A., N. Reul, G. Lagerloef, G. Reverdin, J.A. Carton, B. Chapron, Y. Quilfen, V.N. Kudryavtsev, and H.-Y. Kao. 2012. Haline hurricane wake in the Amazon/Orinco plume: AQUARIUS/SACD and SMOS observations. Geophysical Research Letters 39, L20603, http://dx.doi.org/10.1029/2012GL053335.

Hegerl, G.C., E. Black, R.P. Allan, W.J. Ingram, D. Polson, K.E. Trenberth, R.S. Chadwick, P.A. Arkin, B.B. Sarojini, A. Becker, and others. 2014. Challenges in quantifying changes in the global water cycle. Bulletin of the Meteorological Society, http://dx.doi.org/10.1175/BAMS-D-13-00212.1.

Held, I.M., and B.J. Soden. 2006. Robust responses of the hydrological cycle to global warming. Journal of Climate 19:5,686-5,699, http://dx.doi.org/10.1175/ JCLI3990.1.

Helm, K.P., N.L. Bindoff, and J.A. Church. 2010. Changes in the global hydrological-cycle inferred from ocean salinity. Geophysical Research Letters 37, L18701, http://dx.doi.org/10.1029/ 2010 GL044222.

Holland, H.D. 1972. The geologic history of sea water: An attempt to solve the problem. Geochimica et Cosmochimica Acta 36(6):637-651, http://dx.doi.org/10.1016/0016-7037(72)90108-1.

Hosoda, S., T. Suga, N. Shikama, and K. Mizuno. 2009. Global surface layer salinity change detected by Argo and its implication for hydrological cycle intensification. Journal of Oceanography 65:579-596, http://dx.doi.org/ 10.1007/s10872-009-0049-1.

Huffman, G.J., R.F. Adler, P. Arkin, A. Chang, R. Ferraro, A. Gruber, J. Janowiak, A. McNab, B. Rudolf, and U. Schneider. 1997. The Global Precipitation Climatology Project (GPCP) combined precipitation dataset. Bulletin of the American Meteorology Society 78:5-20, http://dx.doi.org/10.1175/1520-0477(1997)078 $<0005$ :TGPCPG>2.0.CO;2. 
Huffman, G.J., D.T. Bolvin, E.J. Nelkin, D.B. Wolff, R.F. Adler, G. Gu, Y. Hong, K.P. Bowman, and E.F. Stocker. 2007. The TRMM Multisatellite Precipitation Analysis (TMPA): Quasi-global, multiyear, combined-sensor precipitation estimates at fine scales. Journal of Hydrometeorology 8:38-55, http://dx.doi.org/10.1175/JHM560.1.

Ishii, M., and M. Kimoto. 2009. Reevaluation of historical ocean heat content variations with time-varying XBT and MBT depth bias corrections. Journal of Oceanography 65:287-299, http://dx.doi.org/ 10.1007/s10872-009-0027-7.

Ishii, M., M. Kimoto, K. Sakamoto, and S.-I. Iwasaki. 2006. Steric sea level changes estimated from historical ocean subsurface temperature and salinity analyses. Journal of Oceanography 62:155-170, http://dx.doi.org/10.1007/s10872-006-0041-y.

Johnson, G.C., and J.M. Lyman. 2007. Global oceans: Sea surface salinity. Supplement to State of the Climate in 2006. A. Arguez, ed. Bulletin of the American Meteorological Society 88:s34-s35, http://dx.doi.org/10.1175/ BAMS-88-6-StateoftheClimate.

Josey, S.A., S. Gulev, and L. Yu. 2013. Exchanges through the ocean surface. Pp 115-140 in Ocean Circulation and Climate: $A$ 21st Century Perspective. G. Siedler, S.M. Griffies, J. Gould, and J.A. Church, eds, International Geophysics, vol. 103, Academic Press, Elsevier, Oxford, UK, http://dx.doi.org/10.1016/ B978-0-12-391851-2.00005-2.

Kidd, C., and G. Huffman. 2011. Global precipitation measurement. Meteorological Applications 18:34-353.

Kirtman, B.P., T. Stockdale, and R. Burgman. 2013. The ocean's role in modeling and predicting seasonal-to-interannual climate variations. Pp. 625-643 in Ocean Circulation and Climate: A 21st Century Perspective. G. Siedler, S.M. Griffies, J. Gould, and J.A. Church, eds, International Geophysics, vol. 103, Academic Press, Elsevier, Oxford, UK, http://dx.doi.org/10.1016/ B978-0-12-391851-2.00024-6.

Lagerloef, G., F.R. Colomb, D. Le Vine, F. Wentz, S. Yueh, C. Ruf, J. Lilly, J. Gunn, Y. Chao, A. deCharon, and others. 2008. The Aquarius/SAC-D mission: Designed to meet the salinity remote-sensing challenge. Oceanography 21(1):68-81, http://dx.doi.org/ 10.5670/oceanog.2008.68.

Lagerloef, G., F. Wentz, S. Yueh, H.-Y. Kao, G.C. Johnson, and J.M. Lyman. 2012. Global oceans: Aquarius satellite mission provides new detailed view of sea surface salinity. Supplement to State of the Climate 2011. J. Blunden and D.S. Arndt, eds. Bulletin of the American Meteorology Society 97:S70-S71, http://dx.doi.org/ 10.1175/2012BAMSStateoftheClimate.1.

Latif, M. 2013. The ocean's role in modeling and predicting decadal climate variations. Pp. 645-665 in Ocean Circulation and Climate: A 21st Century Perspective. G. Siedler, S.M. Griffies, J. Gould, and J.A. Church, eds, International Geophysics, vol. 103, Academic Press, Elsevier, Oxford, UK, http://dx.doi.org/10.1016/ B978-0-12-391851-2.00025-8.

Lee, T., G. Lagerloef, M.M. Gierach, H.-Y. Kao, S. Yueh, and K. Dohan. 2012. Aquarius reveals salinity structure of tropical instability waves. Geophysical Research Letters 39, L12610, http://dx.doi.org/ 10.1029/2012GL052232.

Levitus, S., J.I. Antonov, T.P. Boyer, H.E. Garcia, and R.A. Locarnini. 2005. Linear trends of zonally averaged thermosteric, halosteric and total steric sea level for individual ocean basins and the world ocean, (1955-1959)-(1994-1998). Geophysical Research Letters 32, L16601, http://dx.doi.org/ 10.1029/2005GL023761.
Li, G., and S.-P. Xie. 2014. Tropical biases in CMIP5 multimodel ensemble: The excessive equatorial Pacific cold tongue and double ITCZ problems. Journal of Climate 27:1,765-1,780, http://dx.doi.org/ 10.1175/JCLI-D-13-00337.1.

Lin, J.-L. 2007. The double-ITCZ problem in IPCC AR4 coupled GCMs: Ocean-atmosphere feedback analysis. Journal of Climate 20:4,497-4,525, http://dx.doi.org/10.1175/JCLI4272.1.

Maidment, R.I., D. Grimes, R.P. Allan, E. Tarnavsky, M. Stringer, T. Hewison, R. Roebeling, and E. Black. 2014. The 30 year TAMSAT African Rainfall Climatology and Time series (TARCAT) data set. Journal of Geophysical Research: Atmospheres 119:10,619-10,644, http://dx.doi.org/ 10.1002/2014JD021927.

Polade, S.D., A. Gershunov, D.R. Cayan, M.D. Dettinger, and D.W. Pierce. 2013. Natural climate variability and teleconnections to precipitation over the Pacific-North American region in CMIP3 and CMIP5 models. Geophysical Research Letters 40:2,296-2,301, http://dx.doi.org/10.1002/ grl.50491.

Reverdin, G. 2010. North Atlantic subpolar gyre surface variability (1895-2009). Journal of Climate 23:4,571-4,584, http://dx.doi.org/ 10.1175/2010JCLI3493.1.

Rhein, M., S.R. Rintoul, S. Aoki, E. Campos, D. Chambers, R.A. Feely, S. Gulev, G.C. Johnson, S.A. Josey, A. Kostianoy, and others. 2013. Observations: Ocean. Pp. 255-315 in Climate Change 2013: The Physical Science Basis. Contribution of Working Group I to the Fifth Assessment Report of the Intergovernmental Panel on Climate Change. T.F. Stocker, D. Qin, G.-K. Plattner, M. Tignor, S.K. Allen, J. Boschung, A. Nauels, Y. Xia, V. Bex, and P.M. Midgley, eds, Cambridge University Press, Cambridge, UK, and New York, NY, http://dx.doi.org/10.1017/ CBO9781107415324.010.

Richter, I., and S.-P. Xie. 2008. On the origin of equatorial Atlantic biases in coupled general circulation models. Climate Dynamics 31:587-598, http://dx.doi.org/10.1007/s00382-008-0364-z.

Roemmich, D., and J. Gilson. 2009. The 2004-2008 mean and annual cycle of temperature, salinity, and steric height in the global ocean from the Argo program. Progress in Oceanography 82:81-100, http://dx.doi.org/10.1016/j.pocean.2009.03.004.

Rubey, W.W. 1951. Geologic history of sea water: An attempt to state the problem. Bulletin of the Geological Society of America 62(9):1,111-1,148, http://dx.doi.org/10.1130/0016-7606(1951)62 [1111:GHOSW]2.0.CO;2

Schanze, J.J., R.W. Schmitt, and L.L. Yu. 2010 The global oceanic freshwater cycle: A stateof-the-art quantification. Journal of Marine Research 68:569-595, http://dx.doi.org/ $10.1357 / 002224010794657164$.

Schmitt, R.W. 1995. The ocean component of the global water cycle. Reviews of Geophysics 33(S2):1,395-1,409, http://dx.doi.org/ 10.1029/95RG00184.

Schmitt, R.W. 2008. Salinity and the global water cycle. Oceanography 21(1):12-19, http://dx.doi.org/ 10.5670/oceanog.2008.63.

Skliris, N., R. Marsh, S.A. Josey, S.A. Good, C. Liu and R.P. Allan. 2014. Salinity changes in the world ocean since 1950 in relation to changing surface freshwater fluxes. Climate Dynamics 43:709-736, http://dx.doi.org/10.1007/s00382-014-2131-7.

Steffen, K., R.H. Thomas, E. Rignot, J.G. Cogley, M.B. Dyurgerov, S.C.B. Raper, P. Huybrechts, and E. Hanna. 2010. Cryospheric contributions to sea-level rise and variability. Pp. 178-225 in Understanding Sea-Level Rise and Variability. J.A. Church, P.L. Woodworth, T. Aarup, and W.S. Wilson, eds, Wiley-Blackwell, Oxford, UK, http://dx.doi.org/10.1002/9781444323276.
Talley, L.D. 2008. Freshwater transport estimates and the global overturning circulation: Shallow, deep and throughflow components. Progress in Oceanography 78:257-303, http://dx.doi.org/ 10.1016/j.pocean.2008.05.001.

Taylor, K.E., R.J. Stouffer, and G.A. Meehl. 2012. An overview of CMIP5 and the experiment design. Bulletin of the American Meteorological Society 93:485-498, http://dx.doi.org/10.1175/ BAMS-D-11-00094.1.

Trenberth, K.E., L. Smith, T. Qian, A. Dai, and J. Fasullo. 2007. Estimates of the global water budget and its annual cycle using observational and model data. Journal of Hydrometeorology 8:758-769, http://dx.doi.org/ 10.1175/JHM600.1.

van der Ent, R.J., and H.H. Savenije. 2013. Oceanic sources of continental precipitation and the correlation with sea surface temperature. Water Resources Research 49:3,993-4,004, http://dx.doi.org/10.1002/wrcr.20296.

van der Ent, R.J., H.H.G. Savenije, B. Schaefli, and S.C. Steele-Dunne. 2010. Origin and fate of atmospheric moisture over continents. Water Resources Research 46(9), W09525, http://dx.doi.org/ 10.1029/2010WR009127.

von Schuckmann, K., F. Gaillard, and P.-Y. Le Traon. 2009. Global hydrographic variability patterns during 2003-2008. Journal of Geophysical Research 114(C9), C09007, http://dx.doi.org/ 10.1029/2008JC005237.

Williams, P.D., E. Guilyardi, G. Madec, S. Gualdi, and E. Scoccimarro. 2010. The role of mean ocean salinity in climate. Dynamics of Atmospheres and Oceans 49:108-123, http://dx.doi.org/10.1016/ j.dynatmoce.2009.02.001.

Williams, P.D.E., Guilyardi, R.T. Sutton, J.M. Gregory, and G. Madec. 2006. On the climate response of the low-latitude Pacific Ocean to changes in the global freshwater cycle. Climate Dynamics 27:593-611, http://dx.doi.org/10.1007/ s00382-006-0151-7.

Williams, P.D., E. Guilyardi, R. Sutton, J. Gregory, and G. Madec. 2007. A new feedback on climate change from the hydrological cycle. Geophysical Research Letters 34, L08706, http://dx.doi.org/ 10.1029/2007GL029275.

Wong, A.P.S, N.L. Bindoff, and J.A. Church. 1999. Large-scale freshening of intermediate waters in the Pacific and Indian oceans. Nature 400:440-443, http://dx.doi.org/ $10.1038 / 22733$

Wüst, G. 1936. Oberflächensalzgehalt, Verdunstung und Niederschlag auf dem Weltmeere. Länderkundliche Forschung, Festschrift Norbert Krebs, 347-359.

AUTHOR. Paul J. Durack (pauldurack@llnl.gov) is Research Scientist, Program for Climate Model Diagnosis and Intercomparison, Lawrence Livermore National Laboratory, Livermore, CA, USA.

\section{ARTICLE CITATION}

Durack, P.J. 2015. Ocean salinity and the global water cycle. Oceanography 28(1):20-31, http://dx.doi.org/ 10.5670/oceanog.2015.03. 